\title{
Thrombotic Microangiopathy Associated with Carbon lon Radiotherapy and Chemotherapy for Osteosarcoma: a Case Report
}

\author{
Yosuke Hirabayashi $^{1} \cdot$ Kan Katayama $^{1}$ (D) $\cdot$ Yutaka Toyomasu $^{2} \cdot$ Kunihiro Asanuma $^{3} \cdot$ Shoko Mizoguchi $^{1} \cdot$ Keiko Oda $^{1}$. \\ Takayasu Ito $^{1} \cdot$ Tomohiro Murata $^{1} \cdot$ Eiji Ishikawa $^{1} \cdot$ Masaaki Ito $^{1}$
}

Accepted: 3 July 2019 / Published online: 10 July 2019

(C) The Author(s) 2019

\section{Background}

Osteosarcoma is a primary malignant tumor that arises from the bone and is observed commonly at a relatively young age [1]. Therapy for operable osteosarcoma consists of the combination of operation and chemotherapy, and radiation therapy is thought to be relatively ineffective [2]. However, radiation therapy in combination with chemotherapy is chosen for cases of inoperable osteosarcoma [3].

Three-drug regimens, such as methotrexate, doxorubicin, and cisplatin, have been reported to show a better outcome concerning the 5-year event-free survival or overall survival than two-drug regimens in chemotherapy for osteosarcoma [4]. However, kidney injury due to chemotherapy drugs is reported to occur more frequently with cisplatin, ifosfamide, and methotrexate than with doxorubicin [5].

Radiation-associated kidney injury was reported to be caused by 10 - to 20 -Gray total body irradiation [6]. Compared with photons, carbon ions provide a higher linear energy transfer and larger relative biological effectiveness (RBE). Carbon ion radiotherapy (CIRT) is suitable for local irradiation and is reported to be effective for unresectable osteosarcoma of the spine [7].

We herein report a case of chronic kidney injury associated with carbon ion radiotherapy and chemotherapy for inoperable osteosarcoma.

This article is part of the Topical Collection on Medicine

Kan Katayama

katayamk@clin.medic.mie-u.ac.jp

1 Department of Cardiology and Nephrology, Mie University Graduate School of Medicine, 2-174 Edobashi, Tsu, Mie 514-8507, Japan

2 Department of Radiology, Mie University Hospital, Tsu, Japan

3 Department of Orthopaedic Surgery, Mie University Graduate School of Medicine, Tsu, Japan

\section{Case Presentation}

An 18-year-old man developed lumbago 2 years earlier and was found to have a tumor mass at the L2 lumbar vertebra on abdominal computed tomography (CT) (Fig. 1a). Although a CT-guided biopsy did not lead to a definitive diagnosis, an open biopsy of the vertebra led to a diagnosis of osteosarcoma. The osteosarcoma was inoperable, so chemotherapy with methotrexate, doxorubicin, and cisplatin was given six times.

His renal function remained within the normal range (serum creatinine $-0.73 \mathrm{mg} / \mathrm{dL}$, creatinine clearance$102.2 \mathrm{~mL} / \mathrm{min}$, urinary $\beta_{2}$-microglobulin $\left(\beta_{2} \mathrm{mg}\right)$ $36 \mu \mathrm{g} / \mathrm{L}$ ), and CIRT with 64 Grays (RBE) in 16 fractions was performed for 4 weeks starting 3 months after the diagnosis. The carbon ion dose was expressed as the photonequivalent dose in Gray (RBE). The designated area and dose volume histogram for CIRT are shown in Fig. $1 \mathrm{~b}$ and c, respectively. After CIRT, chemotherapy with methotrexate, doxorubicin, cisplatin, and ifosfamide was initiated. His serum creatinine and urinary $\beta_{2} \mathrm{mg}$ levels started to increase during second-line chemotherapy, which was completed 11 months after the diagnosis. His serum creatinine and urinary $\beta_{2} \mathrm{mg}$ levels continued to increase from the month after the completion of second-line chemotherapy. His renal dysfunction progressed gradually over the next 9 months, and he was admitted to our hospital for the evaluation of the renal dysfunction (Fig. 2).

His height was $164 \mathrm{~cm}$, and his body weight was $61 \mathrm{~kg}$. His body temperature was $36.5^{\circ} \mathrm{C}$, his pulse was $65 / \mathrm{min}$, and his blood pressure was $117 / 59 \mathrm{mmHg}$. There was no abnormality under a physical examination. Urinary examinations were as follows: occult blood, negative; protein, $0.42 \mathrm{~g} / \mathrm{gCr} ; \mathrm{N}$ acetyl- $\beta$-D-glucosaminidase, $16.6 \mathrm{U} / \mathrm{L}$; and $\beta_{2} \mathrm{mg}$, $23051 \mu \mathrm{g} / \mathrm{L}$ (Table 1). Pan-aminoaciduria was detected. A laboratory test showed the following results: hemoglobin, $14.8 \mathrm{~g} / \mathrm{dL}$; platelets, $23.5 \times 10^{4} / \mu \mathrm{L}$; blood urea nitrogen, $14.8 \mathrm{mg} / \mathrm{dL}$; serum creatinine, $1.37 \mathrm{mg} / \mathrm{dL}$; estimated 

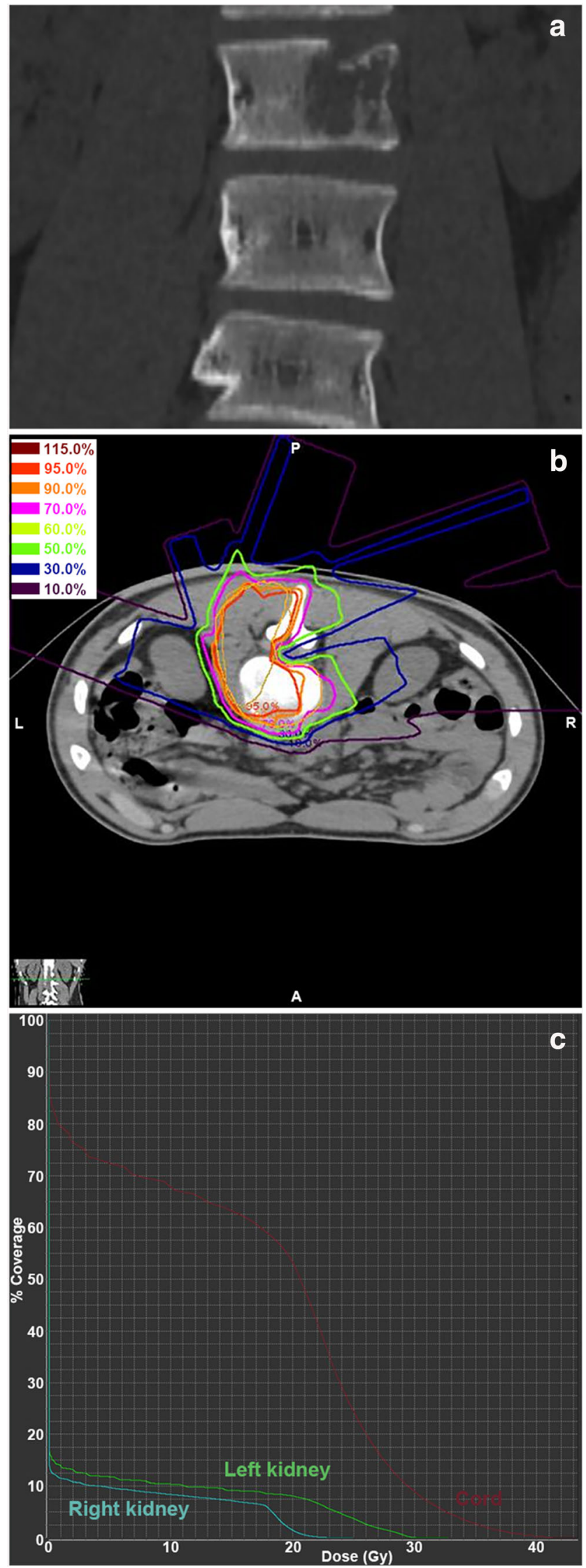

C

(a)

4 Fig. 1 a Abdominal computed tomography showed a tumor mass in the L2 lumbar vertebra. b The area designated to receive carbon ion radiotherapy. $\mathbf{c}$ The dose volume histogram of carbon ion radiotherapy

glomerular filtration rate (eGFR), $60.0 \mathrm{~mL} / \mathrm{min} / 1.73 \mathrm{~m}^{2}$; uric acid, $2.5 \mathrm{mg} / \mathrm{dL}$; and inorganic phosphate, $2.5 \mathrm{mg} / \mathrm{dL}$. Immunoglobulin $\mathrm{G}$ (IgG), IgA, IgM, complement 3 (C3), $\mathrm{C} 4$, and hemolytic complement 50 (CH50) were within normal ranges.

The kidney tissue that was obtained from the lower pole of the left kidney showed global sclerosis in 7 of 43 glomeruli. Tubulointerstitial injury was observed in $40 \%$ of the total area. There were red globules in the lumen or mesangial area on Masson trichrome staining (Fig. 3). Expansion of the mesangial matrix and mesangiolysis were noted on periodic acid-Schiff (PAS) staining (Fig. 3). There were diffuse global double contours of the glomerular basement membrane (GBM) on periodic acid methenamine silver (PAM) staining (Fig. 3). An immunofluorescence study showed that the globules were positive for IgG, IgA, or IgM (Fig. 4). An electron microscopic study showed edematous change in the subendothelial part of the GBM and mesangial interposition (Fig. 4). These findings were compatible with thrombotic microangiopathy. Immunohistochemistry results showed positive staining for 8-hydroxy-2'-deoxyguanosine $(8-\mathrm{OHdG})$ in the glomeruli of the patient (Fig. 5). Although he was not hypertensive, the angiotensin receptor blocker candesartan was started at $2 \mathrm{mg}$ per day for radiation nephropathy, with the dose increased to $4 \mathrm{mg}$ per day due to progressive renal dysfunction. His estimated glomerular filtration rate is $47.5 \mathrm{~mL} / \mathrm{min} / 1.73 \mathrm{~m}^{2}$, and no recurrence of osteosarcoma has been noted in the past 4 years.

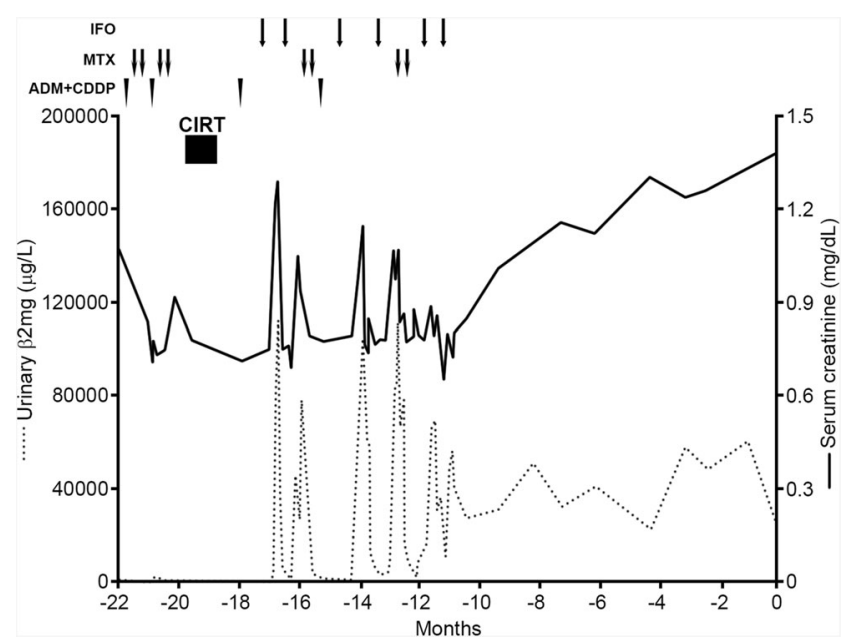

Fig. 2 The clinical course before admission 
Table 1 The laboratory data on admission
Fig. 3 Expansion of the mesangial matrix and mesangiolysis was noted on hematoxylin and eosin (HE) or periodic acid-Schiff (PAS) staining. There were red globules in the lumen or mesangial area on Masson trichrome (MT) staining. There were diffuse global double contours of the glomerular basement membrane on periodic acid methenamine silver (PAM) staining. Scale bars, $50 \mu \mathrm{m}$

\begin{tabular}{llll}
\hline Urinary examination & & Blood chemistry & \\
\hline $\mathrm{pH}(4.5-7.5)$ & 5.5 & $\mathrm{TP}(\mathrm{g} / \mathrm{dL}, 6.6-8.1)$ & 6.9 \\
Protein $(\mathrm{g} / \mathrm{gCr})$ & 0.42 & $\mathrm{Alb}(\mathrm{g} / \mathrm{dL}, 4.1-5.1)$ & 4.4 \\
Occult blood & $(-)$ & $\mathrm{BUN}(\mathrm{mg} / \mathrm{dL}, 8-20)$ & 14.8 \\
Glucose $(\mathrm{mg} / \mathrm{dL})$ & $(-)$ & $\mathrm{Cr}(\mathrm{mg} / \mathrm{dL}, 0.46-0.79)$ & 1.37 \\
$\beta_{2} \mathrm{mg}(\mu \mathrm{g} / \mathrm{L}, 5-253)$ & 23051 & $\mathrm{eGFR}\left(\mathrm{mL} / \mathrm{min} / 1.73 \mathrm{~m}^{2}\right)$ & 60 \\
$\mathrm{NAG}(\mathrm{U} / \mathrm{L}, 1.0-4.2)$ & 16.6 & $\mathrm{UA}(\mathrm{mg} / \mathrm{dL}, 2.6-5.5)$ & 2.5 \\
& & $\mathrm{Na}(\mathrm{mEq} / \mathrm{L}, 138-145)$ & 141 \\
Complete blood count & & $\mathrm{K}(\mathrm{mEq} / \mathrm{L}, 3.6-4.8)$ & 3.4 \\
WBC $(/ \mu \mathrm{L}, 3300-8600)$ & 5110 & $\mathrm{Cl}(\mathrm{mEq} / \mathrm{L}, 101-108)$ & 103 \\
RBC $\left(\times 10^{4} / \mu \mathrm{L}, 386-492\right)$ & 489 & $\mathrm{HCO}{ }^{-}(\mathrm{mmol} / \mathrm{L})$ & 27.6 \\
Hb $(\mathrm{g} / \mathrm{dL}, 11.6-14.8)$ & 14.8 & $\mathrm{Ca}(\mathrm{mg} / \mathrm{dL}, 8.8-10.1)$ & 9.2 \\
Plt $\left(\times 10^{4} / \mu \mathrm{L}, 15.8-34.8\right)$ & 23.5 & $\mathrm{IP}(\mathrm{mg} / \mathrm{dL}, 2.7-4.6)$ & 2.5 \\
& & $\mathrm{Mg}(\mathrm{mg} / \mathrm{dL}, 1.8-2.4)$ & 2.3 \\
Serology & & $\mathrm{IgG}(\mathrm{mg} / \mathrm{dL}, 861-1747)$ & 1127 \\
ANA & & $\mathrm{IgG} 4(\mathrm{mg} / \mathrm{dL}, 4-108)$ & 41 \\
anti-SSA antibody $(\mathrm{U} / \mathrm{mL}, 0-7.0)$ & $<40$ & $\mathrm{IgA}(\mathrm{mg} / \mathrm{dL}, 93-393)$ & 142 \\
anti-SSB antibody $(\mathrm{U} / \mathrm{mL}, 0-7.0)$ & $<0.5$ & $\mathrm{IgM}(\mathrm{mg} / \mathrm{dL}, 50-269)$ & 66 \\
Anti-mitochondrial M2 antibody $(\mathrm{U} / \mathrm{mL}, 0-7.0)$ & 0.6 & & \\
\hline
\end{tabular}

$\beta_{2} m g$ 32-microglobulin, $N A G$ N-acetyl- $\beta$-D-glucosaminidase, $W B C$ white blood cells, $R B C$ red blood cells, $H b$ hemoglobin, Plt platelets, $A N A$ antinuclear antibody, $T P$ total protein, $A l b$ albumin, $B U N$ blood urea nitrogen, $C r$ creatinine, $e G F R$ estimated glomerular filtration rate, $\mathrm{UA}$ uric acid, $\mathrm{Na}$ sodium, $\mathrm{K}$ potassium, $\mathrm{Cl}$ chloride, $\mathrm{HCO}_{3}{ }^{-}$ bicarbonate ion, $\mathrm{Ca}$ calcium, $I P$ inorganic phosphates, $M g$ magnesium, $I g$ immunoglobulin
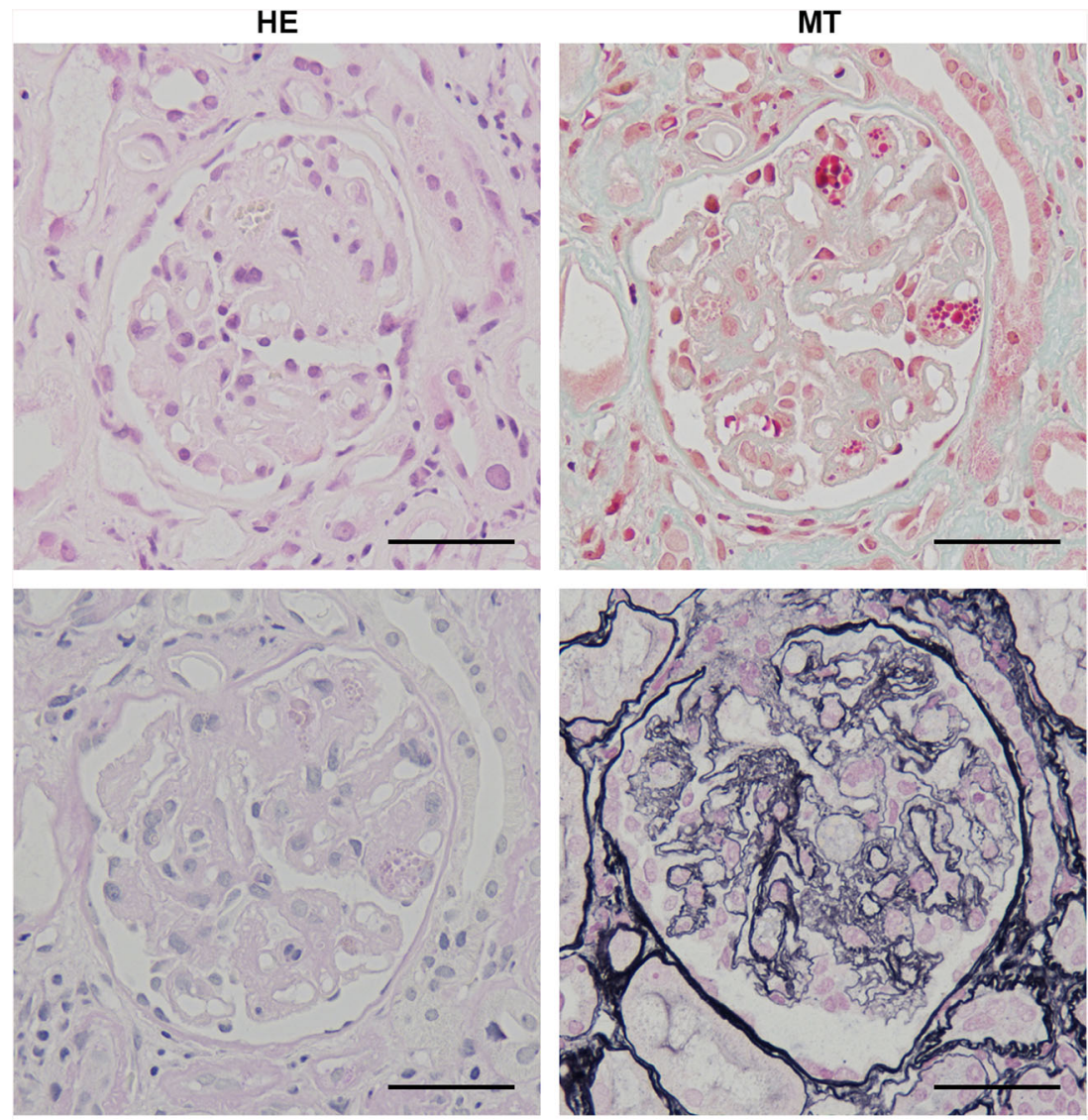

PAS

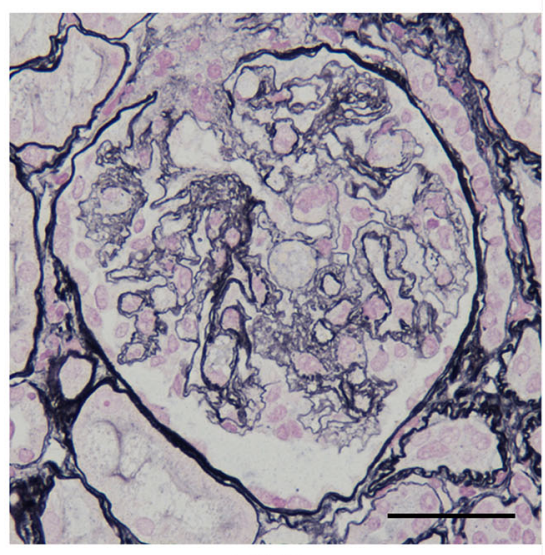

PAM 
Fig. 4 There were globules that were positive for $\operatorname{IgG}, \operatorname{IgA}$, or $\mathrm{IgM}$ in the capillary lumen on an immunofluorescence study. Scale bars, $50 \mu \mathrm{m}$. There were edematous changes in the subendothelial part of the glomerular basement membrane and mesangial interposition on an electron microscopic study. Scale bar, $2 \mu \mathrm{m}$
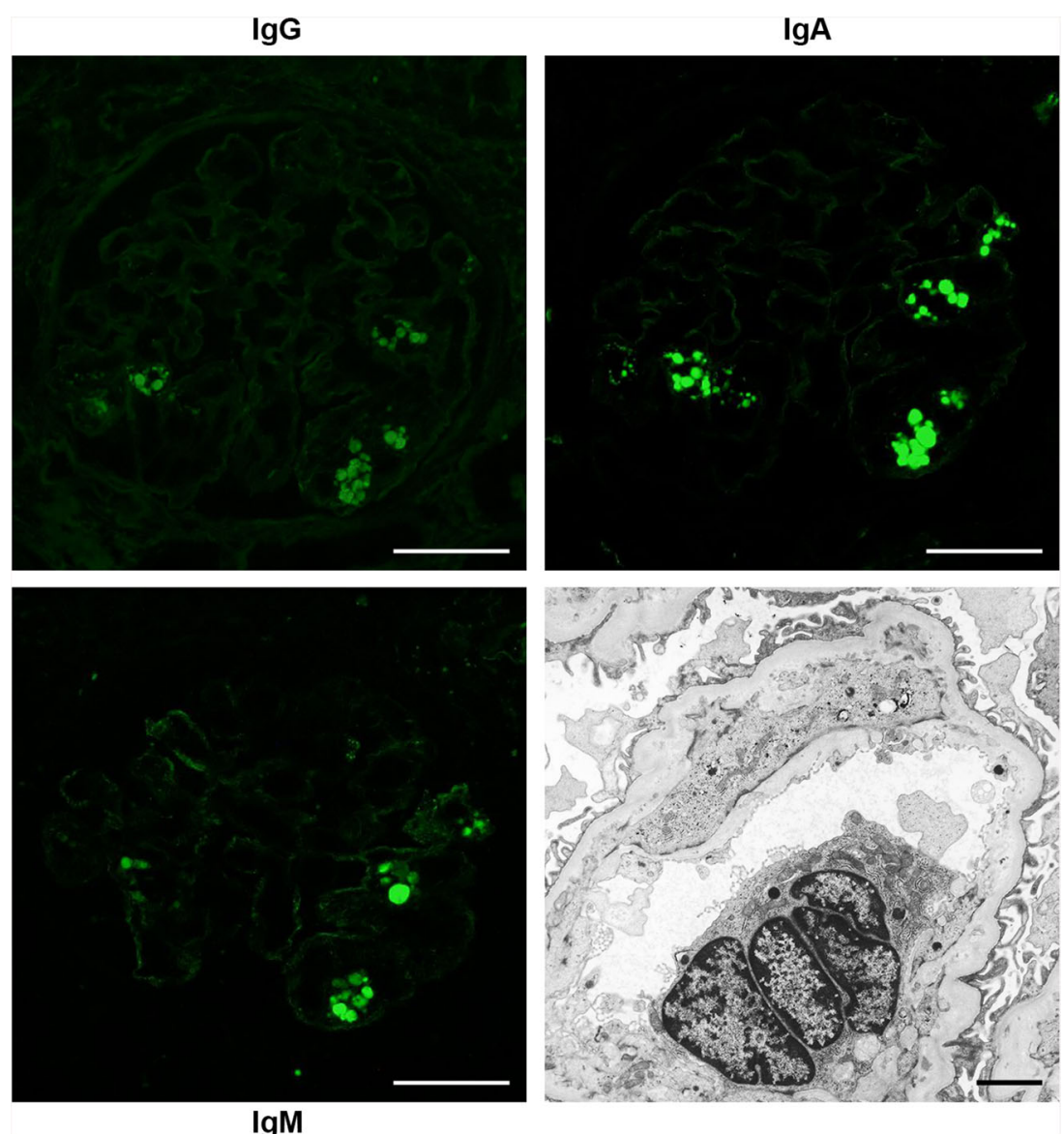

\section{Discussion and Conclusion}

We experienced a case of inoperable osteosarcoma in the L2 lumbar vertebra wherein the patient developed progressive kidney injury after treatment with a combination of chemotherapy and CIRT. While there was no apparent kidney injury during first-line chemotherapy or CIRT, his kidney function became exacerbated after second-line chemotherapy, and a kidney biopsy was performed 1.5 years after the completion of the combined therapy. Surprisingly, the kidney pathology was compatible with thrombotic microangiopathy due to late-onset endothelial cell damage, which might imply indolent changes after radiation therapy, as the expression of $8-\mathrm{OHdG}$ was observed in the glomeruli.

There was also a possibility that second-line chemotherapy caused the kidney injury in the present case. The cumulative doses of ifosfamide, methotrexate, doxorubicin, and cisplatin were $81 \mathrm{~g} / \mathrm{m}^{2}, 96 \mathrm{~g} / \mathrm{m}^{2}, 120 \mathrm{mg} / \mathrm{m}^{2}$, and $480 \mathrm{mg} / \mathrm{m}^{2}$, respectively. The present case showed mild Fanconi syndrome without hypomagnesemia, which might reflect nephrotoxicity due to ifosfamide and/or cisplatin.

The etiology to the tubulointerstitial damage in the present case might be related to drugs or CIRT. Since chemotherapy drugs have been reported to increase the kidney toxicity of radiation [8], the first-line chemotherapy in the present case might have increased the kidney toxicity following CIRT. The serum creatinine and urinary $\beta_{2} \mathrm{mg}$ levels increased after second-line chemotherapy in the present case, suggesting that CIRT might potentiate toxicity of second-line chemotherapy in a similar way.

Since the osteosarcoma originated at the L2 lumbar vertebra in our patient, it might be difficult to prevent any effects of CIRT on the kidneys for anatomical reasons. However, CIRT was designed to reduce the offtarget effect to both kidneys by controlling the breathing of the patient. The expected exposure to the lower pole of the left kidney was around 20-30 Grays (RBE), since it was planned to be $30-50 \%$ of 64 Grays (RBE), and the dose volume histogram showed that around 20 Grays (RBE) corresponded to 7.5-10\% coverage of the left kidney. Nevertheless, the renal pathology showed thrombotic microangiopathy along with the formation of immune complexes in the capillary lumen, suggesting the systemic activation of the immune system by local irradiation, since the expression of 8-OHdG was observed in the glomeruli. We failed to detect thrombotic microangiopathy at the upper pole of the kidney that had not been irradiated 


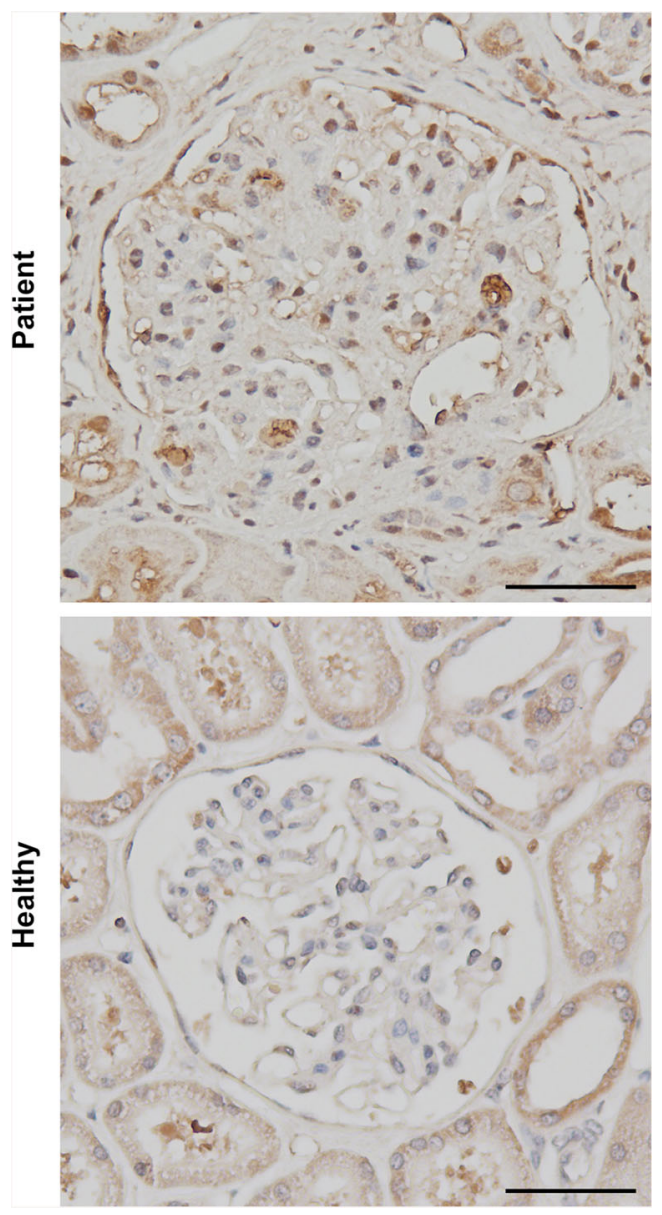

Fig. 5 Staining for 8-hydroxy-2'-deoxyguanosine (8-OHdG) was positive in the kidney of the patient but not in healthy kidney. Scale bars, $50 \mu \mathrm{m}$

by CIRT because informed consent for such an assessment was not obtained from the patient. However, a previous report in a zebrafish model described the systemic effect rather than the direct effect of irradiation on the kidney [9].

We experienced a case of osteosarcoma in which progressive kidney injury developed after combination therapy of chemotherapy and CIRT. CIRT can cause thrombotic microangiopathy, similar to conventional radiation therapy. Careful follow-up may be necessary when chemotherapy and CIRT are combined.

\section{Compliance with Ethical Standards}

Competing Interests M.I. received departmental scholarship funds of $\geq$ $1,000,000$ yen per year for direct expenses from MSD K.K.; BristolMyers Squibb; Biotoronik Japan, Inc.; Astellas Pharma, Inc.; Shionogi \& Co., Ltd.; and Otsuka Pharmaceutical Co., Ltd., in 2015; MSD K.K.; Astellas Pharma, Inc.; Takeda Pharmaceutical Company, Ltd.; Daiichi Sankyo Company, Ltd.; and Otsuka Pharmaceutical Co., Ltd., in 2016; and MSD K.K.; Shionogi \& Co.; Otsuka Pharmaceutical Co., Ltd.; Takeda Pharmaceutical Company, Ltd.; and Daiichi Sankyo Company, Ltd., in 2017. The companies associated with this funding were not involved in the manuscript preparation or the decision to publish the present case report. All other authors have no conflicts of interest to declare.

Consent for Publication Written informed consent was obtained from the patient for the publication of this case report.

Open Access This article is distributed under the terms of the Creative Commons Attribution 4.0 International License (http:// creativecommons.org/licenses/by/4.0/), which permits unrestricted use, distribution, and reproduction in any medium, provided you give appropriate credit to the original author(s) and the source, provide a link to the Creative Commons license, and indicate if changes were made.

\section{References}

1. Mirabello L, Troisi RJ, Savage SA. International osteosarcoma incidence patterns in children and adolescents, middle ages and elderly persons. Int J Cancer. 2009;125:229-34.

2. Schwarz R, Bruland O, Cassoni A, Schomberg P, Bielack S. The role of radiotherapy in oseosarcoma. Cancer Treat Res. 2009;152:147-64.

3. DeLaney TF, Park L, Goldberg SI, Hug EB, Liebsch NJ, Munzenrider JE, et al. Radiotherapy for local control of osteosarcoma. Int J Radiat Oncol Biol Phys. 2005;61:492-8.

4. Anninga JK, Gelderblom H, Fiocco M, Kroep JR, Taminiau AH, Hogendoorn PC, et al. Chemotherapeutic adjuvant treatment for osteosarcoma: where do we stand? Eur J Cancer. 2011;47:2431-45.

5. Perazella MA. Onco-nephrology: renal toxicities of chemotherapeutic agents. Clin J Am Soc Nephrol. 2012;7:1713-21.

6. Dawson LA, Kavanagh BD, Paulino AC, Das SK, Miften M, Li XA, et al. Radiation-associated kidney injury. Int J Radiat Oncol Biol Phys. 2010;76:S108-15.

7. Matsunobu A, Imai R, Kamada T, Imaizumi $T$, Tsuji $H$, Tsujii $H$, et al. Impact of carbon ion radiotherapy for unresectable osteosarcoma of the trunk. Cancer. 2012;118:4555-63.

8. Phillips TL, Wharam MD, Margolis LW. Modification of radiation injury to normal tissues by chemotherapeutic agents. Cancer. 1975;35:1678-84.

9. Nagata K, Hashimoto C, Watanabe-Asaka T, Itoh K, Yasuda T, Ohta $\mathrm{K}$, et al. In vivo 3D analysis of systemic effects after local heavy-ion beam irradiation in an animal model. Sci Rep. 2016;6:28691.

Publisher's Note Springer Nature remains neutral with regard to jurisdictional claims in published maps and institutional affiliations. 